\section{New Records of the Shrimps Hymenopenaeus tropicalis and Parapenaeus americanus from Brazil}

A SMALL number of unknown shrimps were among the material obtained from one station $\left(24^{\circ} 25^{\prime} \mathrm{S} ., 44^{\circ} 40^{\prime} \mathrm{W}\right.$.), about 40 miles south-east of Punta do Boi, São Sebastião Island, in June 1962, on a muddy bottom and at a depth of $130 \mathrm{~m}$. These were kindly identified by Dr. F. A. Chace, jun., of the Smithsonian Institute, as Hymenopenaeus tropicalis (Bouvier) and Parapenaeus americanus Rathbun(?). According to Dr. Chace the latter could be an undescribed species, on the basis of apparent thelycal differences, but no final statement could be made before some adult specimens were examined. The specimens of $P$. americanus (one male and two females) had a total length of 47 and $48 \mathrm{~mm}$ respectively. So far as can be ascertained, both species have not previously been encountered from Brazilian waters.

The occurrence of some lesser-known shrimps along the coastal waters of South America has already been described by Mistakidis and Neiva ${ }^{1}$. Among the species referred to were Sicyonia dorsalis Kingsley and Trachypeneus constrictus (Stimpson). Both species were obtained from hauls made near Santos (about $24^{\circ} \mathrm{S}$.), and were considered as first records from Brazil.

Since then the material collected during the exploratory survey of January-February 1963 along the Santa Catarina coast has been re-examined and it is of interest to observe that the distribution of these species extended farther south than Santos.

A single female $S$. dorsalis (45 $\mathrm{mm}$ total length) and seven specimens of $T$. constrictus (two males and five females, $52-63 \mathrm{~mm}$ total length) were found in material obtained from one station $\left(26^{\circ} 53^{\prime} \mathrm{S} .4^{\circ} 33^{\prime} \mathrm{W}\right.$.) a few miles off the coast. The haul contained also one Sicyonia typica, three Hymenopenaeus mulleri, twenty-cight Penaeus aztecus and thirty-four Xiphopeneus kroyeri. Three female $T$. constrictus were impregnated, and the spermatophores of one male were well developed (February 1). The bottom was mud grading to sand and the depth was $21 \mathrm{~m}$. Another impregnated female T. constrictus $(50 \mathrm{~mm}$ total length) was obtained from another haul made about 12 miles south of this station, also on a muddy bottom, but in shallower water. In addition to the accompanying fauna the 30-min trawl haul contained three Penaeus schmitti and $430 \mathrm{X}$. kroyeri. More detailed information on the distribution and abundance of these and other species obtained during the survey has been given in a mimeographed report published by the Departamento Estadual de Caça e Pesca de Santa Catarina².

Fisheries Development Institute,

$$
\text { M. N. Mrstakidis }
$$

United Nations Special Fund Project, Santiago, Chile.

\section{G. DE S. NeIvA}

Servico de Investigações sobre a Pesca Maritima, Santos, Brazil.

${ }^{1}$ Mistakidis, M. N., and Neiva, G. de S., Nature, 202, 471 (1964).

- Relatorio do Projecto de Pesca Exploratoria na costa de Santa Catarina. Janeiro-Fevereiro, 1963 (Florianopolis, S. Catarina, 1964)。

\section{Records of Macrobrachium carcinus (Linnaeus) and Macrobrachium acanthurus (Wiegmann), from Santa Catarina, Brazil}

Among unidentified material kept at the Fish and Wildlife Service Laboratory at Florianopolis, capital of the State of Santa Catarina, were several specimens of the freshwater prawn Macrobrachium. These were identified as $M$. carcinus and $M$. acanthurus. The two specimens of $M$. carcinus, of 200 and $210 \mathrm{~mm}$ total length (oxcluding the second pair of pereiopods, which measured $230 \mathrm{~mm}$ ), wero from Lagoa da Conceição, a brackish to freshwater lagoon on the Santa Catarina Island. The eight specimens of $M$. acanthurus, of 80-140 mm total length (excluding the second pair of pereiopods, which measured up to $120 \mathrm{~mm}$ in length), were from Rio Pinheira $\left(27^{\circ} 50^{\prime} \mathrm{S}\right.$.), a small river on the mainland, about 3 miles south of the southernmost tip of S. Catarina Island. Local fishermen stated that $M$. carcinus had occasionally been taken from Rio Pinheira, but this could not be verified.

According to Holthius ${ }^{1,2}$ the distribution of both species extends from Georgia and Florida in the United States, to South Brazil, including the West Indies. Holthius ${ }^{1}$ lists several records of $M$. carcinus from Brazil, including the State of Santa Catarina, the southernmost locality being the Rio Itajai. As the Lagoa da Conceição is approximately 40 miles south of Itajai the distribution appears to extend farther south than was previously known.

The distribution of $M$. acanthurus extends farther south than $M$. carcinus, and it has been recorded as far south and west as Itaqui, on the River Uruguay, and from São Lourenço, Rio Grande do Sul, Brazil's southernmost state. However, the species had not previously been recorded from Rio Pinheira.

\section{N. Mistakidis}

Fisheries Development Institute,

United Nations Special Fund Project,

Santiago, Chile.

${ }^{1}$ Holthius, L. B., Occ. Pap. Allan Hancock Found., No. 12 (1952).

${ }^{2}$ Holthius, L. B., Zool. Verhand., No. 44 (1959).

\section{Plasminogen Activator in Saliva of the Vampire Bat Desmodus rotundus}

IT was generally accepted that vampire bats wore blood. sucking animals until 1932 when Dunn ${ }^{1}$ observed that these animals use their tongues to lap blood from freely bleeding wounds inflicted by means of razor-sharp superior incisors. This observation was confirmed by Ditmars and Greenhall ${ }^{2}$ and by many subsequent investigators, and it has been noticed that bites inflicted by vampire bats not only bleed very freely when the wound is first made, but also continue to bleed for several hours after the bat has ceased to feed ${ }^{3}$. It is therefore of interest to investigato the mechanism by which vampire bat saliva brings about this degree of interference with the haemostatic mechanism of the host animal.

The presence of an anticoagulant in saliva of Desmodus rotundus has been suggested by several workers including Romana and $\mathrm{Mann}^{3}$, and dissolution of blood clots containing $D$. rotundus saliva was noted by Bier ${ }^{5}$. DiSanto ${ }^{6}$ roported that addition of a saline suspension of the principal submaxillary gland to fibrin brought about hydrolysis and suggested that a proteolytic substance in the gland was responsible for this. In the present investigation the effect of saliva from $D$. rotundus on platelet adhesiveness and aggregation, blood coagulation, fibrinolysis and vasoconstriction has been investigated and it has been demonstrated that the saliva increases vascular permeability and contains a potent plasminogen activator. Preliminary tests for inhibition of platelet adhesiveness to glass surfaces and aggregation of platelets by adenosine diphosphate have given negative results and tests for anticoagulant activity have been inconclusive. Some characteristics of the plasminogen activator are reported here.

Tests have been carried out on two specimens of D. rotundus in captivity at the London Zoological Gardens. A small drop of pilocarpine hydrochloride was applied to the buccal mucosa with a fine polythene Pasteur pipette and approximately $2 \mathrm{~min}$ later it was possible to collect saliva by means of a second polythene pipette. This process could be carried out without handling the animals. Saliva was obtained in a similar manner from normal laboratory mice for comparative tests. The saliva was 